\title{
Meiotic Studies of Induced Auto-octoploid Spironema fragrans Lindle
}

\author{
R. N. Singh and A. N. Sahi \\ Centre of Advanced Study in Botany, Banaras Hindu \\ University, Varanasi-5, India
}

Accepted September 12, 1991

Spironema fragrans Lindle is vegetatively propagated perennial herb and grows wild in the climate of Varanasi (U. P.). Genus is interesting because it represents the intermediate step in the evolution of Commelineae from Tradescantieae (Roy 1967). Diploid plant has regular meiosis, produces healthy pollen with high fertility but no seed setting (Gupta and Roy 1973). No seed setting was observed inspite of high pollen fertility in induced autotetraploids of $S$. fragrans (Singh and Roy 1990). The auto-octoploid $(2 n=8 x=48)$ was induced in $S$. fragrans with aim to testore fertility and factors responsible for seed setting. The present observation deals the meiotic chromosome association, behaviour and fertility in auto-octoploid $S$. fragrans in detail.

\section{Materials and methods}

Developing twenty five shoots of Spironema fragrans Lindle (family Commelinaceae) were treated with $0.50 \%$ aqueous solution of colchicine for two successive mornings. Cytological studies, pollen size and fertility were studied in treated plant and compared with the normal (diploid) plant. Pollen fertility and size were observed using $1 \%$ acetocarmine solution. For meiotic studies, young spikes were fixed in 1:3 acetic alcohol for $24 \mathrm{~h}$. Anthers were squashed in $1 \%$ acetocarmine solution. Observations were taken from fresh preparation and slides were made permanent by t-butyl alcohol schedule. Somatic chromosomes were also studied for the confirmation of the level of ploidy in the present observations.

\section{Observations}

Out of twenty five shoots were treated, six shoots $(24 \%)$ were observed autotetraploid and only one $(4 \%)$ turned out as auto-octoploid. Diploid $S$. fragrans reveal 6 bivalents at their diakinesis and metaphase I (Fig. 1) while auto-octoploid showed $2 n=8 x=48$ chromosomes (Fig. 2). Chromosome configuration in octoploid was irregular and vary from cell to cell. The mean chromosome association was $0.50 \mathrm{uni}, 11.00 \mathrm{bi}, 2.00$ tetra, 0.25 hexa and 2.00 octovalents at diakinesis and 0.67 uni, $7 \mathrm{bi}, 2.33$ tetra and 3 octovalents at metaphase. At metaphase I, the number of bivalents were less and consistent presence of tetra- and octovalents were observed. Octovalents were generally ring and chain shaped in the present study. With the increase of chromosomes, the number of chiasmata per cells also increased (diploid 12.64, octoploid 37.15) but the chiasma frequency per bivalent decreased (diploid 2.11 to octoploid 1.54 ). Increase in the chromosome number was accompanied by the increase in cell size (Table 1).

Chromosome behaviour in the diploid was almost normal while auto-octoploid showed highly abnormal chromosome behaviour in 65.95 percent cells. Irregular chromosome behaviour such as lagging chromosomes, bridge, clumping, unequal separation and at last, forma- 
tion of micronuclei, were frequently observed. Laggards usually led to the formation of micronuclei or disappeared by disintegration, ultimately resulting into abnormal microspores.

The size of pollen grains in the auto-octoploid was more in comparison to their diploid. Pollen fertility was directly related to the meiotic abnormalities and present plant showed less fertility $(64.92 \%)$ than diploid $(93 \%)$. The presence of 24 somatic chromosomes at metaphase in pollen tube of the treated plant confirmed the octoploidy of the plant (Fig. 4, Table 2). Instead of high pollen fertility, the auto-octoploid showed the complete failure of seed setting.

Table 1. Chromosome association, chiasma frequency and pollen fertility in diploid and auto-octoploid $S$. fragrans

\begin{tabular}{|c|c|c|c|c|c|c|c|c|c|}
\hline \multirow{2}{*}{ Generation } & \multirow{2}{*}{$\begin{array}{l}\text { PMC's } \\
\text { studied }\end{array}$} & \multicolumn{6}{|c|}{ Mean chromosome association } & \multirow{2}{*}{ 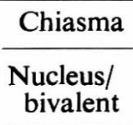 } & \multirow{2}{*}{$\frac{\text { Pollen }}{\text { fertility }}$} \\
\hline & & Uni & $\mathrm{Bi}$ & Tri & Tetra & Нexa & Octo & & \\
\hline $\begin{array}{l}\text { Diploid } \\
(2 n=2 x=12)\end{array}$ & 10 & - & 6.00 & - & - & - & - & $\begin{array}{r}12.66 \\
2.11\end{array}$ & 93.00 \\
\hline $\begin{array}{l}\text { Octoploid } \\
(2 n=8 x=48)\end{array}$ & 10 & 0.50 & 11.00 & - & 2.00 & 0.25 & 2.00 & $\begin{array}{r}37.15 \\
1.54\end{array}$ & 64.92 \\
\hline
\end{tabular}

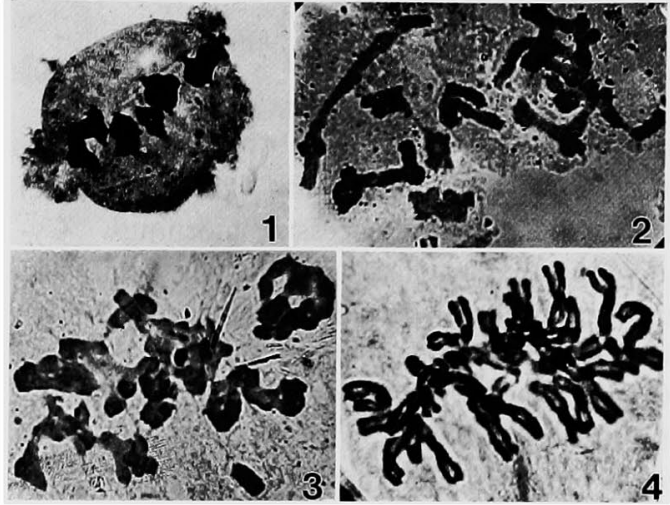

Figs. 1-4. Meiosis of diploid and auto-octoploid S. fragrans. $\times 500$. 1, Diploid showing 6 bivalents at metaphase I. 2, Auto-octoploid showing $5 \mathrm{II}+$ $2 \mathrm{IV}+1 \mathrm{VI}+3 \mathrm{VIII}$ at diakinesis. 3, Autooctoploid showing $2 \mathrm{I}+13 \mathrm{II}+1 \mathrm{IV}+2 \mathrm{VIII}$ at metaphase I. 4, Haploid chromosomes (24) at metaphase $I$ in germinating pollen tube.
Table 2. Chromosomal abnormalities at anaphase I/II in auto-octoploid $S$. fragrans

\begin{tabular}{lc}
\hline \hline Chromosomal abnormalities & Auto-octoploid \\
\hline PMCs & 150 \\
Anaphase I/Telophase I & \\
Laggard & 21.45 \\
Bridge & 10.50 \\
Laggard + Bridge & 3.10 \\
Anaphase II/Telophase II & \\
Laggard & 12.00 \\
Bridge & 5.00 \\
Laggard + Bridge & 1.00 \\
Polysporad stage & 12.90 \\
Total abnormalities & 65.95 \\
\hline
\end{tabular}

All figures are per cent values.

\section{Discussion}

It is difficult to produce experimentally high ploidy levels (higher than $4 n=4 x$ chromosomes) by means of colchicine. In allopolyploids, it is little easier to obtain the higher level than autopolyploids. Stebbins (1949) produced 16n form different species of the Bromus carinatus complex. In dicot, Acalypha wilkesiana has a level of $32 \mathrm{n}$ (Darlington and Wylie 1961) and 16-18n are not rare in gramineae. The allo-octoploids seem to be in general more viable than the auto-octoqloid and very few auto-octoploids are reported viz. Nicotiana longiflora (Kostoff 1938), Lycopersicon esculentum (Gottschalk 1959), Bryophyllum daigremontianum (Schwanitz 1961), Brassica oleracea var. capitata (Shchavinskaya 1973), Cochlearia (Gupta 1981), Petunia axillaris (Padmaja 1985), Hyoscyamus muticus (Dhavan and Tyagi 
1989). Autoploids of even higher ploidy levels are very rare as reported in Vicia villosa (Hertzsch 1951), 12n Antirrhinum majus (Straub 1940), 12n S. nigrum (Singh and Roy 1982) and $16 \mathrm{n}$ in tomato (Gottschalk 1959). Gottschalk (1978) pointed out that octoploid show generally an extraordinarily negative selection with regard to metabolism, vitality, and fertility. On the other hand cell size was bigger than those of the autotetraploid.

Dhavan and Tyagi (1989) observed gigas characteristics especially in leaves, stem thickness, flower parts, stomata and pollen grains and suggested that the plant growth and development are inhibited beyond a certain optimal ploidy level and further duplication cause disharmonious growth. Rothfels et al. (1966) and Stebbins (1971) reported that polyploidization is one of the mechanisms for increasing DNA content in plants while Gupta (1981) suggested that the amount of DNA increases significantly more during the first period of chromosome doubling than during the second.

The meiosis of auto-octoploid was highly irregular and chromosome association varied from low to high multivalents in the PMC's. Pollen mother cells showed low number of octovalents along with dominance of bi- and tetravalents. Present study supports the view of Morrison and Rajhathy (1960), Padmaja (1985) and Dhavan and Tyagi (1989) having low frequency of multivalents. Irregular meiosis with clumping, lagging chromosome at anaphase I/II and unequal separation of chromosomes were prevalent in the present auto-octoploid $S$. fragrans. It was confirmed that meiotic instability increases with increasing the level of ploidy.

Reduced pollen fertility was observed with bigger size of pollen grains. Multivalent formation and their irregular separation is responsible for sterility in autopolyploids (Darlington 1937). Some auto-octoploids reported in literature are formed as complete sterile (Gottschalk 1959, Shchavinskaya 1973) to partial fertile (Kostoff 1938, Dhavan and Tyagi 1989) and highly fertile (Schawanitz 1961). Dhavan and Tyagi (1989) reported irregular meiotic behaviour of chromosomes as well as genetic and physiological factors responsible for poor or no seed setting. Auto-octoploid $S$. fragrans showed consistent presence of fertile pollen grains and healthy ovules but inability to set seeds. However, it was not clear whether the abortive seeds were the remians of the unfertilized ovules or the unsuccessful seeds. It seems that some genetic mechanism inhibits the seed formation from diploid to higher ploidy (8n) level and chromosome doubling does not help in seed setting.

\section{Summary}

Highest ploidy $(2 \mathrm{n}=8 \mathrm{x}=48)$ was observed in $S$. fragrans. Meiosis of auto-octoploid showed consistent presence of multivalents in lower frequencies. Meiosis at $8 \mathrm{n}$ level was highly irregular with exceptionally high pollen fertility. Absence of seed setting from diploid to octoploid level concludes that some genic mechanism operating during fertilization inhibits the seed formation.

\section{Acknowledgement}

Authors are grateful to the Head, Department of Botany, Banaras Hindu University for providing facilities and RNS is thankful to University Grants Commission, New Delhi for financial assistance as RA. 


\section{References}

Darlington, C. D. 1937. Recent Advances in Cytology. Philadelphia, pp. 671.

- and Wylie, A. P. 1961. Chromosome Atlas of Flowering Plants. London: George Allen.

Dhavan, O. P. and Tyagi, B. R. 1989. Cytomorphological studies on induced auto-octoploid of Egyptian Henbane (Hyoscyamus muticus L.). Cytologia 54: 307-312.

Gupta, P. P. 1981, Consequences of artificial and natural chromosome doubling on DNA, RNA and protein contents in Corhlearia (Brassieaceae). Pl. Syst. Evol. 138: 23-27.

- and Roy, S. K. 1973. Meiosis in Spironema fragrans Lindle. Curr. Sci. 42: 291-292.

Gottschalk, W. 1959. Morphologische und Cytologische Untersuchungen an experimentell erzeugten hochpolyploiden Pflanzen. Cytologia 24: 181.

- 1978. Open problems in polyploidy research. Nucleus 21 : 99-112.

Hertzsch, W. 1951. Beobachtungen an polyploider Vicia villosa. Z. Pflanzenzuchtung 30: 210.

Kostoff, D. 1938. Colchicine and acenaphthene as polyploidizing agents. Nature 142: 753.

Morrison, J. W. and Rajhathy, T. 1960. Frequency of quadrivalents in autotetraploid plants. Nature 187: 528.

Padmaja, V. 1985. Cytomorphology of auto-octoploid Petunia axillaris (Lam) BSP. Ch. Inf. Serv. $39: 37-39$.

Rothfels, K., Sexsmith, E., Heimburger, M. and Krause, M. C. 1966 . Chromosome size and DNA content of species of Anemone L. and related genera (Ranunculaceae). Chromosoma 20: 54-74.

Roy, S. K. 1967. Application of a modified schedule in clarification of the cytology of Spironema fragrans Lindle. Sci. Cult. 33: 377-378.

Schwanitz, F. 1961. Fertilitat und Sexualitat. Eine Untersuchung uber die Ursachen ver minderter Samen produktion bei Polyploiden. Züchter $31: 183$.

Shchavinskaya, S. A. 1973. Octoploid cabbage experimentally obtained. Bull. Appl. Bot. Gen. Plant Breed. Ser. II: 7: 69 .

Singh, R. N. and Roy, S. K. 1982. A contribution to cytology of Solanum nigrum complex. Curr. Sci. 51: $572-573$.

- and - 1990. Induction of colchiploidy in Spironema fragrans Lindle. Cytobios 64: 111-119.

Stebbins, G. L. 1949. The evolutionary significance of natural and artificial polyploids in the family Gramineae. Proc. 8th Intern. Cong. Genet. Stockholm. Hereditas Suppl. Vol. 461.

- 1971. Chromosome Evolution in Higher Plants. Arnold, London.

Straub, J. 1940. Quantitative and qualitative Verschiedenheiten innerhalb von polyploiden Pflanzenreihen. Biol. Zblatt. $60: 659$. 